\title{
FROM ZERO TO INFINITY: \\ THE USE OF IMPACT FACTORS IN THE EVALUATION OF ECONOMIC RESEARCH IN SPAIN*
}

\section{IE Working Paper $\quad$ CG8-106-I 13-05-2005}

Salvador Carmona

Instituto de Empresa Business School

Calle María de Molina, 12-5

28006 Madrid (Spain)

salvador.carmona@ie.edu
Antonio García-Ferrer

Pilar Poncela

\author{
Universidad Autónoma de Madrid \\ Dpto. de Análisis Económico \\ Economía Cuantitativa \\ 28049 Cantoblanco (Spain) \\ antonio.garcia@uam.es
}
Universidad Autónoma de Madrid
Dpto de Análisis Económico
Economía Cuantitativa
28049 Cantoblanco (Spain)

\begin{abstract}
Studies on assessments of research performance in economic departments largely rely upon such bibliometric tools as impact factors to rank a short list of journals. In the present study, we examine the use of short lists of journals in order to assess research performance in Spain - a country that features a rare combination of a thin and incomplete academic market along with an elite of eminent economists. Our analysis reveals that the implementation of bibliometric tools to produce short lists of journals for assessment purposes entail problems with the statistical significance of cutoff rates, neglect of the interdisciplinary nature of economics, and an inability to track progress in academic markets that move towards internationalization and publications in top-tier, premier outlets.
\end{abstract}

Keywords

Research assessment; Economic departments; Impact factors; Journal rankings; Spain

We are grateful for financial support received from the Spanish Ministry of Education, Grants Contracts PB-20020081, SEJ-2004-08176-C02-01, and SEC03-3797. We appreciate the many helpful suggestions made by the reviewers of Research Policy on earlier drafts of this paper. 



\section{Introduction}

The different sets of institutional characteristics across systems of higher learning in Europe and North America exert considerable influence on the criteria that are employed for the assessment of research and for career advancement in those two geographic locations (Bosch, 2003; Whitley, 2003). In the case of economics, the large and impersonal North American market enforces "output" measures of performance, which result in the use of "a reliable indicator of an individual scholar's quality: his or her journal publications and citation record" (Frey and Eichenberger, 1992: 216). In contrast, Europe features an academically closed and highly regulated market (Portes, 1987), which focuses instead on the academic "process" and, hence, on such aspects as the success with which scholars have passed formal examinations, or their membership in a particular school of thought (Frey and Eichenberger, 1993).

Recent studies have highlighted issues surrounding the assessment of European research in economics and econometrics (Eichenberger and Frey, 2000; Lubrano and Protopopescu, 2004). Such exercises usually draw on a core number of journals, selected on the grounds of their impact factors and cited half-life indexes, to produce rankings of economics departments and institutions (Kalaitzidakis, Mamuneas and Stengos, 1999, 2003). Although such investigations have advanced understanding about patterns of economic research across European countries, they have also attracted severe criticism. First, assessments of the research performance of individual countries inevitably penalize countries like the UK, with numerous economic departments (Lubrano and Protopopescu, 2004), supporting the contention that differences among the various academic systems of different countries should be taken into account (Moed and Luwel, 1999). Second, the use of impact factors compiled by the Institute of Scientific Information (ISI) may have "inappropriate and counterproductive consequences" (Moed, 2002: 731) if applied to countries and regions (e.g., Europe) with research traditions that differ from those enshrined in the bibliometric indexes under consideration (e.g., North America). Finally, there is the contentious issue of reliance on a short list of journals as constituting a consistent and comprehensive measure of economic research. The interdisciplinary nature of economics as well as the need to consider publication forms other than journal articles suggest the need for a wider scope of data sources (Nederhof, 1989).

In the present study, we analyze these concerns by focusing on the case of Spain -a country that blends a rare combination of conformity with the tradition of the European market of academics (Frey and Eichenberger, 1993) with three placements in the top 20 institutions of economic research in Europe (Kalaitzidakis et al, 2003). We argue that this situation renders Spain a relevant setting to examine criteria of research assessment in economics, and to embed this exercise into the wider contexts of the country's system of higher learning. Yet, we seek to advance understanding on (i) the use of bibliometric tools published annually by the ISI's Journal Citation Reports (JCR) in order to produce journal rankings, which in turn constitute the basis for the evaluation of economic departments; and (ii) the implications of using a core number of journals for research assessment in an interdisciplinary field like economics. 
In the next section of this paper, we examine the institutional contexts of higher learning in Spain and how they affect the generation and diffusion of economics research. This discussion is followed by an analysis of the use of impact factors in journal rankings and the implications of using short lists of journals in order to assess research output in this area. We then perform a statistical analysis of journals targeted by economists and included in ISI's JCR, covering areas such as economics, business and finance, management, planning and development, mathematical social sciences, and statistics and probability, during the period 1991-2003. Finally, we discuss our results, make policy recommendations, and suggest further research in this area.

\section{The Institutional Contexts of Economic Departments in Spain}

The earliest school of political and economic sciences was established in Madrid in 1943. Because there were no opportunities to obtain postgraduate economics education in Spain at the time, the founding faculty members of the school came from diverse backgrounds. The subjects included in the curriculum, therefore, ranged from economic theory to law through mathematics, statistics and econometrics, public economics, economic policy, economic geography, accounting, and business economics. Furthermore, the academic approach of that period did not distinguish between research and teaching, so it was not uncommon for instructors in applied subjects to use their $\mathrm{PhD}$ theses as textbooks in undergraduate courses. The first cohorts of economists combined an interdisciplinary background with a solid education in basic subjects.

The Spanish university system was highly centralized. University professors across the country received low, flat compensation packages, which failed to discriminate according to scholarly performance. Moreover, the processes of tenure and promotion were held at the national level through six public tests, which resulted in membership in an academic school of thought (Frey and Eichenberger, 1993), and the identity of one's PhD supervisor often carrying more weight in the hiring process than did the applicant's research outcome (Bosch, 2003). Furthermore, tenured scholars became civil servants, which, under the existing legislation, allowed only Spanish citizens to become eligible for job openings. The small number of opening positions covered highly specialized subjects that prevented cross-field teaching among tenured faculty. A professor of econometrics, for example, could not teach related subjects such as economic theory. In short, economics within the Spanish system of higher learning illustrated the case of a self-contained and highly regulated market (Portes, 1987).

In such contexts, the research of Spanish academics was rarely published in international journals. Up until the early 1980s, only a handful of Spanish economists, typically educated in well regarded universities in the UK or the USA, presented their research at international conferences or were published in top-tier, premier outlets. In contrast, the overwhelming majority of university professors focused on the preparation of primarily unpublished manuscripts and on teaching notes, invited lectures, and books edited by local publishers. Different perspectives on research underlied these two camps: for a few economists research meant publication in top journals, but many others believed that the academic life should be 
aimed at becoming a learned person, and that the outcomes of this process did not necessarily have to be observable.

The University Reform Act (Ley de Reforma Universitaria: LRU) was passed in 1983, and brought about substantial changes in the Spanish system of higher education. The LRU and its accompanying legislation broadened the scope of the academic areas to which university scholars could apply for tenure. Applied economics, for example, comprised subjects such as statistics, economic geography, public policy, economic development, public finance, regional and urban economics, and econometrics. Thus tenured professors could now teach across any of these subject areas by demonstrating their credentials. Furthermore, tenure and promotion were no longer determined by a national system in which prospective candidates were ranked according to their scores on six oral exams, with the top-ranking candidate choosing among whichever universities were offering positons. In the new system, the hiring decision could be heavily influenced by universities themselves, with lesser input from the national body. In 1989, moreover, the Ministry of Education enforced annual assessment of the research publication records of scholars over a six-year period, giving preference to publications in journals listed in the ISI's JCR. Academics obtaining a positive assessment from a national assessment committee (Comité Nacional de Evaluación de la Actividad Investigadora: CNEAI) received formal recognition and financial compensation. In 2002, the Spanish parliament passed an act that required two positive research assessments over a sixyear period in order for full professors to qualify as examiners on tenure committees (in which successful candidates automatically became associate professors) or on committes that promoted successful candidates to full professorships. Associate professors had to receive at least one positive research assessment within a six-year period to become eligible for joining tenure committees.

The reforms enacted by the LRU were accompanied by increasing funding to the Spanish system of higher learning and the creation of 39 new universities, which added to the existing 41, during the period 1980-1995. Additionally, the Spanish Ministry of Education launched a national programme of research and development that granted research projects to groups with an international profile. The concomitant action of liberalizing measures and increased research funding made Spanish universities an attractive place to work, which appealed to a significant number of Spanish scholars who had received their PhDs from well regarded universities in the UK and the USA.

The growth of publications in international journals authored by scholars affiliated with Spanish universities increased dramatically during the 1990s (Bergantiños, da Rocha and Palomé, 2002; Dolado, García-Romero and Zamarro, 2002; Kalaitzidakis et al, 2003). Yet the growth did not spread uniformly among departments, subject fields, or individuals, as exemplified by the high index of polarization (Villar, forthcoming) and its concomitant effect on the success rates of research assessment exercises. Table 1 (Columns 3 and 5) shows the percentage of professors who received at least one positive assessment. As shown in Table 1, the percentages vary across academic areas; whereas $71.8 \%$ of professors in economic theory and quantitative methods have obtained at least one positive assessment, less than half $(34.1 \%)$ the percentage marketing professors have got it. Importantly, differences in research performance across academic areas cannot be attributed to different requirements, as the 
evaluation committee of the research assessment exercise is common to all areas listed in Table 1.

Table 1 to appear around here

Overall, measurement of the research performance of Spanish economists shows some shocking results. Although Spain places some individuals and departments in the elite of economic research, it seems as if scholars behave individually rather than as a group (Eichenberger and Frey, 2000) - that no research team culture has been developed among economics scholars in Spain. Even the state's imposing role in higher learning was not enough to deploy a teamwork culture and the country continues to witness a sharp contrast between a small group of well regarded academics and a majority of scholars, whose work rarely appears in well regarded journals. For example, García, Montañés and Sanz (1999) analyzed the published output of 88 economic departments in the six top Spanish economic journals between 1992 and 1997. Only 27 departments scored above average and faculty members in 44 of the 88 had never published a single article in any of the six journals. This contrasting situation could be at least partially attributed to an ambiguous definition of research goals established by the public authorities, particularly in the field of economics (Jiménez-Contreras et al, 2003). In 2003, for example, only 53\% of total applicants for evaluation of research performance in economics were successful, a figure which is considerably lower than the average across fields (78\%).

Table 2 to appear around here

\section{The JCR, Bibliometric Tools, and Journal Rankings}

Not only do journal rankings constitute the main source of data in research assessments in economics (Van Fleet, McWilliams and Siegel, 2000), but there seems to be a consensus about the significant role of journal articles as predictors of academic impact (Nederhof and Van Raan, 1993: 354). Nederhof (1989) has suggested, however, that books and book chapters should be considered in all research assessments, and we would add research grants to that list.

The impact factor (IF) constitutes a decisive indicator of the diffusion of an academic journal (Davis and Papanek, 1984; Liebowitz and Palmer, 1988), yet it is based on the assumption that "a high number of citations stands for scientific quality" (Van Leeuwen et al., 2003: 262). Once a year the ISI's JCR publishes the IFs of approximately 7,500 world journals covering the sciences, social sciences, humanities, and $\operatorname{arts}^{1}$. Although there is a general acceptance of using IFs, recent bibliometric research has identified a number of caveats that we summarize below (Moed and Van Leeuwen, 1995, 1996; Moed, 2002).

\footnotetext{
${ }^{1} \mathrm{~N}$ onetheless, some areas are still underrepresented in the ISI, and this lack has prompted efforts to build specific databases containing citation analysis as has been done in accounting through the Accounting Research Directory (Brown, Vasarhelyi and Gardner, 1993).
} 
The IF of a journal in Year $\mathrm{T}$ is defined as the number of citations in Year $\mathrm{T}$ to documents published in that journal in years $\mathrm{T}-1$ and $\mathrm{T}-2$, divided by the number of citeable documents published in that journal during T-1 and T-2 (Moed, 1996). In general, citations to articles published in a given year rise sharply to a peak between two and six years after publication. The ISI also publishes two other indicators: the Immediacy Index (II) and the Cited Half-Life (CHL) index. The II is computed by dividing the citations a journal receives in a given year by the number of articles published in that year. Therefore, the II measures the speed at which a journal article is cited upon publication. Finally, the CHL calculates the citation half-life: the number of years it takes for the volume of current citations to decline to $50 \%$ of its initial value. Therefore, the CHL represents a measure of the length of time after publication during which a journal article is cited. Taken together, Van Leeuwen et al (2003) note, each type of indicator reflects "a particular dimension of the general concept of research performance" (p. 258) and therefore a rationale exists for combining bibliometric tools.

Because the IF is still the single measure most commonly used in bibliometric analyses, it is relevant to outline its limitations. First, the notion of a citeable document is not defined by ISI. As noted by Moed (1996: 186), ISI classifies documents into types. In calculating the numerator of the IF, ISI counts citations to all types of documents; whereas citeable documents in the denominator ISI includes as a standard only regular journal articles, notes, and reviews. Consequently, the IF may experience significant variations depending on the journal and type of article. Second, the IF is subject to the statistical effects that impinge on any average value, particularly by the size of the journal and the length of the measurement window. In the case of social science journals, small periodicals that publish less than 35 articles per year may vary their annual IF by $\pm 40 \%$. Although the fluctuation is smaller for larger journals (>140 papers per year), such periodicals are also affected by considerable variation. Finally, the value of the IF is affected by such issues as the number of authors per paper. Or authors with names containing characters not found in the English alphabet Spanish or Chinese authors, for example - may be penalized by the different ways in which their names are spelled from one publication to another.

Some of the problems with IFs refer to field-specific normalization (Van Leeuwen and Moed, 2002). The application of an IF based on field normalization enables the identification of a journal's categories in its own field; journals are first hierarchized within their field and then placed on a cross-field ranking. Once a field normalization is applied, a value of 1 indicates the mean level (world average) for that field and, hence, it becomes meaningful to compare journals across its sub-fields. In a similar vein, top-level journals across different sub-fields are identified by choosing specific deviations from 1 (Van Leeuwen et al., 2003).

Figure 1 shows the results of field-specific normalization for four social science journals during the period 1991 to 2003. The Journal of Forecasting (JF) and International Journal of Forecasting (IJF) are indexed in the IST's Management and Economics fields, both of which publish a similarly small number of articles. The Journal of Economic Dynamics and Control (JEDC) and the American Economic Review (AER) are indexed in the field of economics. Whereas JEDC is a medium-size journal publishing 70-80 articles per year, AER is a large journal which publishes more than 160 articles per year. In these four cases, however, the variation of annual values of their raw IFs is significant. Nonetheless, once we divide their respective IF by the median of their respective fields to perform a field-specific 
normalization, it is possible to make comparisons among the journals. On the one hand, the AER qualifies for top-journal standing because its normalized value is more than three times higher than the median level. On the other hand, JF, IJF, and JEDC fluctuate around the world average, although some differences exist among them.

\section{Figure 1 to appear around here}

The data in Figure 1 depict significant variability in the annual indexes of journals, especially for periodicals with intermediate values in their IFs. This finding concurs with Johnson and Podsakkoff's (1995) result that the reputation of journals changes over time, which has important implications for assessment exercises. For example, how should we assess a journal article published in 1998 within a research assessment for, say, the period 1995-2001? Should we use the IF reported by the ISI for 1998? Or should we consider the mean or the median for the evaluation period? As shown by Amin and Mabe (2000) in their investigation of 30 journals in the field of chemistry, the rankings of journals are contingent upon the time frame under consideration.

Journal rankings obtained from JCR data should account for the age of the periodical as well as the number of journals indexed in an ISI category. In economics, for example, it typically takes five years for new, respectable journals to be indexed in the ISI. This time lag may influence the publication strategy of those working in the field and force scholars to scrutinize a journal's prospects for being indexed in the Social Science Citation Index (SSCI) (Bruin et al., 1993), in order to ensure a fair assessment of their publications. Additionally, some areas such as accounting and finance are underrepresented in the JCR. Reports of the American Association of Collegiate School of Business $\left(\mathrm{AACSB}^{2}\right)$ show that recent $\mathrm{PhDs}$ in this area earn the highest salaries offered by top business schools after finance, which apparently reveals consideration for the work of accounting scholars. Furthermore, the profession of accounting academics is well structured around a number of professional associations that report considerable membership: e.g. the American Accounting Association, with 11,000 members; and the European Accounting Association, with 2,300 members. In spite of these credentials of reputation, size, and organization, the SSCI indexes only seven accounting journals: Accounting, Organizations and Society; The Accounting Review; Auditing: A Journal of Theory and Practice; Journal of Accounting and Economics; Journal of Accounting Research; Journal of Accounting and Economics; and Review of Accounting Studies. This restriction is partly due to existing admission criteria in the SSCI, which require applicants to be cited by journals indexed in the database, making it difficult for periodicals in areas with a small number of SSCI journals to meet the criteria. As for research assessments, the striking outcome is that other equally well regarded journals (e.g., Accounting and Business Research) strive unsuccessfully to be indexed in the database, even though they are regularly used in first-tier universities to assess tenure and promotion decisions, and rank even higher than some SSCI journals in the UK Research Assessment Exercise (Locke and Lowe, 2005). Furthermore, the small number of SSCI journals in accounting has prompted the creation of area-specific databases (e.g., the Accounting Research Directory; British

\footnotetext{
${ }^{2}$ http://www.aacsb.edu/knowledgeservices/SS04ExecutiveSummary.pdf
} 
Accounting Association, under construction), which have been used in citation analyses (Brown and Huefner, 1994; Brown, 1996; Milne, 2002).

\section{The Effects of the Short List of Journals on Research Assessments}

Recent studies have focused on the rankings of economic departments drawing on listings of journals (Kalaitzidakis et al, 1999; 2003; Dolado et al., 2002). Kalaitzidakis et al, commissioned by the European Economic Association drew on a sample of 30 well regarded journals that are included in the rankings because of a complex index computed with data gathered from JCR. In Column 2, Table 3, we show the standings of journals reported by Kalaitzidakis et al (2003); Column 3 displays the rankings of the same journals according to the IF published by the SSCI. As illustrated by the Spearman rank correlation coefficient (0.23), there is considerable variability between the standings reported in Table 3. Furthermore, we concur with Johnson and Podsakkoff (1995) that the standings of journals has often been altered considerably in just a few years. According to the IF data reported in the SSCI, for example, Games and Economic Behavior, which ranked $107^{\text {th }}$ in 2000, jumped to the $55^{\text {th }}$ position in 2001. During the same period, the Oxford Bulletin of Economics \& Statistics jumped from $109^{\text {th }}$ to $47^{\text {th }}$ place.

\section{Table 3 to appear around here}

Reliance on a core list of journals requires that publications not included in the rankings do not qualify as research. This situation, we contend, may have surprising results in assessment exercises. Let us take, for example, the cases of three academics widely considered as being in a class of their own: Andrew Harvey, George C. Tiao, and Arnold Zellner, all of whom held degrees in economics and have been associated with departments of economics and business administration. US Professors Tiao and Zellner retired recently; whereas UK Professor Harvey is probably at the peak of his career. As attested by their personal web pages, all three are actively involved in research. Table 4 summarizes the publishing records of Professors Harvey, Tiao, and Zellner up to 2002. Importantly, just a small portion of the total production of these distinguished academics has appeared in the Kalaitzidakis et al. ranking: 32\% (29 articles) for Harvey, 4\% (5 articles) for Tiao, and 25\% (59 articles) for Zellner.

\section{Table 4 to appear around here}

\section{Statistical Analysis of ISI Journals}

Enlarged lists of journals may overcome some of the shortcomings observed in restricted rankings. In this section, we perform a statistical analysis on the ISI journals included in the JCR 2003, Social Sciences Edition, under the categories of economics, business, finance, planning and development, management, mathematical social sciences, transportation, and statistics and probability. We drew upon data gathered over the period 1991-2003 because, as noted by Van Leeuwen and Moed (2002: 258) "a period of about ten years is needed to assess research performance" (see, for example, Table 9). For simplification purposes, we focused on 2003 data in some of the analyses. 
Table 5 depicts the basic characteristics of journals under each category: the mean, median, maximum and minimum values, and root-squared distance to the mean value (RMSD). Additionally, we created a comprehensive category, "All", which comprises the total number of journals in our database after excluding those that appeared in two or more categories.

\section{Table 5 to appear around here}

We checked for the robustness of our results vis-à-vis outliers: journals publishing a considerable number of review articles that may outperform the IFs of reseach papers. Therefore, we replicated the analysis shown in Table 5 after removing from the list those journals with an IF above or below 3.5 times the RMSD. In the economics category, we identified as outliers the Journal of Economic Literature (IF = 4.243), the Quarterly Journal of Economics (IF = 4.756), and the Journal of Accounting and Economics (IF = 3.844). The Academy of Management Review (IF = 4.415) was the only outlier identified in the management category. Finally, we found two outliers in the statistics and probability category: Bioinformatics (IF = 6.701) and Journal of Computational Biology. (IF = 4.600). These seven journals also appeared as outliers in the "All" category. Table 6 shows the basic characteristics of the journals in the ISI categories after removing the outliers. Obviously, as we identified only outliers in the upper level of the IF, the means decreased in the economics category from 0.767 to 0.697 . Nonetheless, the dispersion of journals measured through RMSD also decreased: in the case of economics, it dropped from 0.754 to 0.546.

\section{Table 6 to appear around here}

Some studies drew on a combination of impact factors and cited half-life indexes used to rank journals:

$$
\mathrm{Aj}=\mathrm{IFj} \times \mathrm{CHLj}
$$

where IFj and CHLj are the impact factor and cited half-life of any journal $\mathrm{j}$. As the ISI does not report $\mathrm{CHLj}$ figures for some journals, especially for new ones, the default value for $\mathrm{CHLj}$ is 1 . Table 7 shows the descriptive values for the journals in our categories after using $\mathrm{Aj}$ as the ranking criterion. However, the correlation coefficient (?) between $\mathrm{Aj}$ and IFj ranks between 0.77 and 0.97 for the ISI categories under study. Therefore, this result provides support for the suggestion of high coherence between both indicators of citation (see Table 8).

\section{------- Table 7 to appear around here --------}

-------- Table 8 to appear around here ---------

Table 9 shows the median IF from 1991 to 2003 for the different ISI categories under investigation. The results show some variability differences among categories as well as a steadily increasing trend in the IFs in most fields; in the cases of business, finance, and management, the median IFs of the final years under study nearly doubled those obtained at the beginning of our observation period. Results obtained for the entire period of study provide support for the descriptive analysis performed for 2003. 
Figure 2 shows the normalized impact factors (NIF) for our entire sample in 2003, in descending order ${ }^{3}$. The results depicted in Figure 2 suggest that the ranking of journals goes down smoothly, with the exception of the outliers mentioned above. Furthermore, such results indicate that the numerical differences between journals do not allow any sensible cluster or discriminant analyses. Yet, the distribution closely mimics the one obtained when us ing the raw IFs.

\section{General Discussion and Conclusions}

Journal listings are used to assess the research performance of individuals and to rank departments. But a crucial issue remains: Which are the criteria that determine the design of the journal listings? Systems of higher learning are heavily influenced by a country's legislation (Perotti, 2002); therefore an examination of the informing criteria of journal listings cannot be disentangled from the wider institutional contexts of the setting. In the present study, we focus on the case of Spain in order to examine the design of journal rankings and its application to economic research.

Spain combines characteristics of the "thin and incomplete" European market of economists with the American one: groups of top economists that are highly output oriented along academics thinking that the results of the research process do not have to be necessarily observable (Frey and Eichenberger, 1993). However, the situation of economic research is dynamic, and the setting is slowly increasing compliance with the characteristics of the American academic market, as predicted Frey and Eichenberger (1992: 220). The trend towards the internationalization of economic research in Spain has been supported by the concomitant effects of the implementation of university reforms and research assessment exercises that qualify scholars to join recruiting committees and that provide financial incentives to those with positive evaluations. Bergantiños et al (2002) found increases of approximately $30 \%$ in the number of pages authored by Spanish scholars in journals indexed in Econlit during the period 1995-1999. Yet Bergantiños et al (2002: 375) assert that international articles of Spanish economists are "biased towards journals outside the SSCI." In the dynamic context of economic research in Spain, we have examined the extent to which existing research exercises provide a fair depiction of progress towards internationalization. As noted by Frey and Eichenberger (1992: 217), the determination of good performance sometimes depends on decisions about the inclusion and exclusion of professional journals.

Recent studies have drawn on short listings of journals in order to rank economic departments (Dolado et al, 2002; Kalaitzidakis et al, 1999; 2003). Our own examination casts some doubts on exercises conducted on this basis. First, our analysis reveals considerable variability in the standings of journals within a relatively short time. Second, there is no statistically significant support for cutting off the number of journals appearing in the listings (see Figure 2 ), which in turn may question the objectivity of the ranking. Finally, short listings of journals set aside the interdisciplinary nature of economics; our analysis of the resumés of three well

\footnotetext{
${ }^{3}$ The NIFs for each journal in our sample may be downloaded from (http://www.uam.es/departamentos/economicas/econcuan/AGF/agf2.htm)
} 
regarded scholars in the field of economics shows that they would obtain unimpressive ratings if their publication records were assessed through short listings of journals ${ }^{4}$.

To tackle some of these problems, we propose the adoption of all SSCI journals in economicrelated disciplines in order to assess research performance. This step, in turn, requires that comparable journals appear in different SSCI fields. Drawing on existing bibliometric research, we have normalized the 405 journals of economic-related fields listed in the JCR Reports, Social Sciences Edition. Our results indicate that the ranking of journals does not vary significantly for outliers when we employ alternative bibliometric tools (e.g., normalized impact factors, combination of cited-half life indexes and impact factors); whereas there is considerable variability in the standings of intermediate-level journals in short periods. Second, our findings indicate that there is no statistical support for narrowing the number of journals. With the exception of the six outliers noted above, the results of the remaining 399 journals in our list decrease smoothly without being possible to perform cluster or discriminant analyses. This, we argue, questions the rationale for using short list of journals in exercises of research assessment.

The application of enlarged versus short listings of journals for assessment of economic research does not substantially affect high performing departments. For example, Thursby (2000), in his investigation of 104 US economic departments, found that there were no statistically significant differences among the top departments (Harvard, Stanford, Chicago, MIT, and Yale were the top five). In a similar manner, Villar (forthcoming) found no significant differences in the rankings of the top 11 economic departments in Spain, after using diverse journal listings. Therefore, the use of comprehensive or short list of journals will primarily affect assessments of research of departments with intermediate profiles. In case of using a short list of journals in evaluations, the research efforts of those moving towards internationalization may be entirely neglected. Yet, in a context that combines hostility from both "traditionalists", who regard them as scholars that abandon the principles of learning and interface with real economy, not least from "high performers", who consider them "newcomers" and lacking academic pedigree (e.g., a $\mathrm{PhD}$ from a well regarded university).

In short, our proposal for using enlarged journal rankings is supported by a combination of technical and policy considerations. Short journal rankings face difficulties with the cutoff point and the need to account for the interdisciplinary nature of economics. At the same time, in settings moving towards internationalization and publications in top-tier, premier outlets, one cannot expect results overnight and, hence, the application of an enlarged list of journals signals the extent of progress.

Our investigation has some limitations that may encourage future work in this area. We have drawn upon normalized impact factors and other bibliometric tools to build up our indexes. However, there is no perfect index and, as noted by Nederhof and Van Raan (1993: 366): "for applied work, especially research aiming at policy-relevant quantitative results, journal

\footnotetext{
${ }^{4}$ We also checked the cases of the 2002 Nobel Prizes in Economics, professors Robert Engle and Clive Granger. Professor Engle published 117 articles in 33 journals, although just 35\% of such production appeared in the Kalaitzidakis et al's ranking, whereas Professor Granger got $20 \%$ out of his 247 articles in such listing.
} 
publication and impact measurement by citation analysis will provide only a tangential measure of research quality and impact." Thus, panels evaluating research should combine different metrics (Van Leeuwen et al, 2003), as well as gather some qualitative information.

\subsection{Policy Recommendations}

Institutions of higher learning are reshaping their focus to adapt to ever-changing circumstances amid constraints of resources. In a context characterized by accountability to stakeholders, there is a trend to produce more with less and report tangible results. In the case of research, this means publishing in top journals and being cited. However, the European market of economists,thin and incomplete, is still slowly moving towards the accomplishment of such goals. In these settings, it is crucial that authorities of systems of higher learning set metrics to measure progress towards internationalization and enable fair assessments of "intermediate" results. In the case of economic research in Spain, this would enhance compliance with targets and diminish the rate of failure in assessments of research performance, as many will likely accommodate their research strategy to established criteria.

In setting metrics to measure performance, authorities of systems of higher learning should also consider the interdisciplinary nature of some fields, like economics. This reconceptualization would require the deployment of comprehensive measures of assessment, such as enlarged journal listings, rather than reliance on a core set of journals. Furthermore, a fair research exercise would require the consideration of other publication forms, such as book chapters and research monographs, which also exert considerable impact on research performed in social sciences. 
Table 1. Number of Full and Associate Professors in Spain in the 1990s and Their Success Rates in Receiving Positive Research Assessments (\%).

\begin{tabular}{|l|l|l|l|l|}
\hline Subject Area & $\begin{array}{l}\text { Number of Full } \\
\text { Professors }\end{array}$ & $\begin{array}{l}\text { Full Professors } \\
\text { Who Received } \\
\text { Positive Research } \\
\text { Assessments } \\
(\%)\end{array}$ & $\begin{array}{l}\text { Number of } \\
\text { Associate } \\
\text { Professors }\end{array}$ & $\begin{array}{l}\text { Associate } \\
\text { Professors Who } \\
\text { Received Positive } \\
\text { Research } \\
\text { Assessments } \\
(\%)\end{array}$ \\
\hline Applied Economics & 291 & 45.7 & 739 & 27.6 \\
\hline Accounting and Finance & 153 & 35.3 & 424 & 19.1 \\
\hline Management & 117 & 39.3 & 302 & 20.8 \\
\hline $\begin{array}{l}\text { Economic Theory } \\
\text { Quantitative Methods }\end{array}$ & 110 & 71.8 & 304 & 51.0 \\
\hline Marketing & 41 & 34.1 & 109 & 28.4 \\
\hline Other Subject Areas & 85 & 75.3 & 175 & 59.4 \\
\hline Total & 797 & 48.9 & 2053 & 31.1 \\
\hline
\end{tabular}

Source: CNEAI, 2002. 
Table 2: Success Rate in Research Assessment by Field of Study (\%).

\begin{tabular}{|l|l|l|l|l|l|l|l|l|l|l|l|l|}
\hline Field Of Study & $\begin{array}{c}1990 \\
(\%)\end{array}$ & $\begin{array}{c}1991 \\
(\%)\end{array}$ & $\begin{array}{l}1992 \\
(\%)\end{array}$ & $\begin{array}{c}1993 \\
(\%)\end{array}$ & $\begin{array}{l}1994 \\
(\%)\end{array}$ & $\begin{array}{l}1995 \\
(\%)\end{array}$ & $\begin{array}{c}1996 \\
(\%)\end{array}$ & $\begin{array}{l}1997 \\
(\%)\end{array}$ & $\begin{array}{c}1998 \\
(\%)\end{array}$ & $\begin{array}{c}1999 \\
(\%)\end{array}$ & $\begin{array}{c}2000 \\
(\%)\end{array}$ & $\begin{array}{c}2001 \\
(\%)\end{array}$ \\
\hline Mathematics/Physics & 59 & 80 & 76 & 78 & 84 & 86 & 90 & 91 & 90 & 90 & 93 & 86 \\
\hline Chemistry & 70 & 75 & 80 & 84 & 74 & 78 & 89 & 92 & 89 & 93 & 96 & 96 \\
\hline $\begin{array}{l}\text { Cell/Molecular } \\
\text { Biology }\end{array}$ & 80 & 74 & 71 & 86 & 82 & 86 & 90 & 92 & 96 & 94 & 99 & 97 \\
\hline Medicine & 59 & 69 & 68 & 65 & 65 & 78 & 75 & 70 & 75 & 76 & 75 & 78 \\
\hline Social Sciences & 46 & 48 & 54 & 70 & 58 & 60 & 64 & 56 & 71 & 62 & 60 & 51 \\
\hline Economics & 47 & 66 & 56 & 60 & 65 & 62 & 50 & 50 & 52 & 54 & 53 & 53 \\
\hline $\begin{array}{l}\text { Average across all } \\
\text { fields }\end{array}$ & 60 & 66 & 65 & 70 & 70 & 71 & 73 & 76 & 78 & 83 & 83 & 78 \\
\hline
\end{tabular}

Source: CNEAI, 2002. 
Table 3. Ranking of Academic Journals in Economics

(Kalaitzidakis et al., 2003 versus IFs in the SSCI)*

\begin{tabular}{|l|l|l|}
\hline Journal & $\begin{array}{l}\text { Ranking in } \\
\text { Kalaitzidakis } \\
\text { et al., 2003 }\end{array}$ & $\begin{array}{l}\text { Ranking in the } \\
\text { SSCI's } \\
\text { Ifs }\end{array}$ \\
\hline American Economic Review & 1 & 10 \\
\hline Econometrica & 2 & 8 \\
\hline Journal of Political Economy & 3 & 9 \\
\hline Journal of Economic Theory & 4 & 52 \\
\hline Quarterly Journal of Economics & 5 & 2 \\
\hline Journal of Econometrics & 6 & 32 \\
\hline Econometric Theory & 7 & 99 \\
\hline Review of Economic Studies & 8 & 22 \\
\hline Journal of Business \& Economic Statistics & 9 & 28 \\
\hline Journal of Monetary Economics & 10 & 30 \\
\hline Games and Economic Behavior & 11 & 43 \\
\hline Journal of Economics Perspectives & 12 & 6 \\
\hline Review of Economics \& Statistics & 13 & 24 \\
\hline European Economic Review & 14 & 39 \\
\hline International Economic Review & 15 & 50 \\
\hline Economic Theory & 16 & 98 \\
\hline Journal of Human Resources & 17 & 36 \\
\hline Economic Journal & 18 & 21 \\
\hline Journal of Public Economics & 19 & 57 \\
\hline Journal of Economic Literature & 20 & 1 \\
\hline Economics Letters & 21 & 124 \\
\hline Journal of Applied Econometrics & 22 & 42 \\
\hline Journal of Economics Dynam. \& Control & 23 & 72 \\
\hline Journal of Labor Economics & 24 & 25 \\
\hline Journal of Environmental Economics \& Management & 25 & 29 \\
\hline Rand Journal of Economics & 26 & 16 \\
\hline Scandinavian Journal of Economics & 27 & 93 \\
\hline Journal of Financial Economics & 28 & 5 \\
\hline Oxford Bulletin of Economic \& Estatistic & 29 & 89 \\
\hline Journal or International Economics & 30 & 27 \\
\hline & & \\
\hline
\end{tabular}

* Spearman rank correlation coefficient: 0.23. 
Table 4. Publishing Records of Professors Harvey, Tiao and Zellner.

\begin{tabular}{|l|l|l|lc|l|l|}
\hline NAME & $\begin{array}{l}\text { Total Journal } \\
\text { Articles }\end{array}$ & $\begin{array}{l}\text { Articles in the } \\
\text { Kalaitzidakis et al. } \\
(2003) \text { list }\end{array}$ & $\begin{array}{l}\text { Articles in } \\
\text { other } \\
\text { Journals }\end{array}$ & $\begin{array}{l}\text { Book Chapters } \\
\text { and Handbooks }\end{array}$ & $\begin{array}{l}\text { Books } \\
\text { Research } \\
\text { Monographs }\end{array}$ \\
\hline A. Harvey & 91 & 29 & 39 & 23 & 3 \\
\hline G. Tiao & 124 & 5 & 88 & 31 & 6 \\
\hline A. Zellner & 230 & 59 & 56 & 114 & 21 \\
\hline
\end{tabular}

Source: The authors. 
Table 5. Descriptive Analysis of the Impact Factor in 8 areas in Economics.

\begin{tabular}{|l|l|l|l|l|l|l|}
\hline FIELD & Number & \multicolumn{2}{l}{ Impact Factor } \\
\hline & & Mean & Median & Maximum & Minimum & RMSD \\
\hline Economics & 169 & 0.767 & 0.566 & 5.243 & 0.000 & 0.754 \\
\hline Business & 57 & 1.031 & 0.741 & 4.415 & 0.082 & 0.874 \\
\hline Finance & 36 & 0.906 & 0.618 & 3.844 & 0.024 & 0.880 \\
\hline Management & 67 & 1.022 & 0.712 & 4.415 & 0.106 & 0.832 \\
\hline Planning & 39 & 0.627 & 0.574 & 1.467 & 0.045 & 0.384 \\
\hline Math Soc & 29 & 0.755 & 0.657 & 2.215 & 0.033 & 0.456 \\
\hline Transport \&* & 12 & 0.662 & 0.595 & 1.158 & 0.025 & 0.276 \\
\hline $\begin{array}{l}\text { Statistics } \\
\text { Probability }\end{array}$ & 75 & 0.868 & 0.598 & 6.701 & 0.099 & 0.968 \\
\hline All & 405 & 0.818 & 0.598 & 6.701 & 0.000 & 0.779 \\
\hline
\end{tabular}

Source: Journal Citation Reports Social Science Edition 2003 and * Science Edition 2003. 
Table 6. Descriptive Analysis of the Impact Factor in 8 Areas in Economics After Removing Outliers.

\begin{tabular}{|l|l|l|l|l|l|l|}
\hline FIELD & Number & Impact Factor & Minimum & RMSD \\
\hline & & Mean & Median & Maximum & Minim \\
\hline Economics & 166 & 0.697 & 0.553 & 3.167 & 0.000 & 0.546 \\
\hline Business & 56 & 0.971 & 0.711 & 3.343 & 0.082 & 0.752 \\
\hline Finance & 36 & 0.906 & 0.618 & 3.844 & 0.024 & 0.880 \\
\hline Management & 66 & 0.970 & 0.697 & 3.343 & 0.106 & 0.722 \\
\hline Planning & 39 & 0.627 & 0.574 & 1.467 & 0.045 & 0.384 \\
\hline Math Soc & 29 & 0.755 & 0.657 & 2.215 & 0.033 & 0.456 \\
\hline Transport & 12 & 0.662 & 0.595 & 1.158 & 0.250 & 0.276 \\
\hline $\begin{array}{l}\text { Statistics } \\
\text { Probability* }\end{array}$ & 73 & 0.736 & 0.597 & 2.753 & 0.099 & 0.529 \\
\hline All & 399 & 0.756 & 0.586 & 3.343 & 0.000 & 0.588 \\
\hline
\end{tabular}

Source: Journal Citation Reports Social Science Edition 2003 and * Science edition 2003. 
Table 7. Descriptive Analysis of the Combined Index (IFs and half-cited life, Aj) in 8 Areas in Economics.

\begin{tabular}{|c|c|c|c|c|c|c|}
\hline \multirow[t]{2}{*}{ FIELD } & \multirow{2}{*}{$\begin{array}{l}\text { Number } \\
\text { Of } \\
\text { Journals }\end{array}$} & \multicolumn{5}{|l|}{$\mathrm{A}_{\mathrm{j}}$} \\
\hline & & Mean & Median & Maximum & Minimum & RMSD \\
\hline Economics & 169 & 5.916 & 3.948 & \begin{tabular}{|l|}
47.560 \\
\end{tabular} & 0.000 & 6.911 \\
\hline Business & 57 & 8.405 & 4.915 & 44.150 & 0.106 & 8.939 \\
\hline Finance & 33 & 7.803 & 5.062 & 33.058 & 0.059 & 8.485 \\
\hline Management & 67 & 7.651 & 4.605 & 44.150 & 0.106 & 8.139 \\
\hline Planning & 39 & 3.801 & 3.076 & 10.670 & 0.045 & 2.751 \\
\hline Math Soc & 29 & 6.769 & 5.410 & 22.150 & 0.033 & 4.800 \\
\hline Transport & 12 & 4.301 & 4.596 & \begin{tabular}{|l|}
10.306 \\
\end{tabular} & 0.250 & 3.027 \\
\hline $\begin{array}{ll}\text { Statistics } & \& \\
\text { Probability* } & \end{array}$ & 75 & 6.506 & 4.621 & 27.530 & 0.203 & 5.686 \\
\hline All & 405 & 6.165 & 4.095 & 47.560 & 0.000 & 6.691 \\
\hline
\end{tabular}

Source: Journal Citation Reports Social Science Edition 2003 and * Science Edition 2003. 
Table 8. Correlation Coefficients of the Impact Factor and $A_{j}$ in 8 Areas in Economics.

\begin{tabular}{|l|l|l|l|l|l|l|l|l|l|}
\hline Field & Economics & Business & Finance & $\begin{array}{l}\text { Manage- } \\
\text { ment }\end{array}$ & Planning & Mathematics & Transport & $\begin{array}{l}\text { Statistics\& } \\
\text { Prob. } *\end{array}$ & All \\
\hline$\rho$ & 0.964 & 0.966 & 0.986 & 0.949 & 0.812 & 0.974 & 0.850 & 0.767 & 0.900 \\
\hline
\end{tabular}

Source: Journal Citation Reports social Science Edition 2003 and * Science Edition 2003. 
Table 9. Median IFs in SSCI Categories (1991-2003)

\begin{tabular}{|c|c|c|c|c|c|c|c|c|c|c|c|c|c|}
\hline IF & Year & & & & & & & & & & & & \\
\hline FIELD & 1991 & 1992 & 1993 & 1994 & 1995 & 1996 & 1997 & 1998 & 1999 & 2000 & 2001 & 2002 & 2003 \\
\hline Economics & 0.375 & 0.323 & 0.353 & 0.410 & 0.442 & 0.449 & 0.443 & 0.460 & 0.468 & 0.482 & 0.559 & 0.554 & 0.566 \\
\hline Business & 0.375 & 0.396 & 0.531 & 0.500 & 0.542 & 0.552 & 0.463 & 0.500 & 0.630 & 0.631 & 0.634 & 0.791 & 0.741 \\
\hline Finance & 0.361 & 0.426 & 0.370 & 0.438 & 0.511 & 0.491 & 0.573 & 0.588 & 0.598 & 0.596 & 0.719 & 0.688 & 0.618 \\
\hline Management & 0.433 & 0.553 & 0.567 & 0.737 & 0.800 & 0.509 & 0.531 & 0.451 & 0.494 & 0.609 & 0.607 & 0.667 & 0.712 \\
\hline Planning & 0.255 & 0.355 & 0.333 & 0.309 & 0.393 & 0.461 & 0.378 & 0.428 & 0.438 & 0.473 & 0.576 & 0.547 & 0.574 \\
\hline Math Soc & $\overline{0.610}$ & 0.621 & 0.369 & 0.426 & 0.531 & 0.682 & 0.622 & 0.748 & 0.699 & 0.607 & 0.610 & 0.569 & 0.657 \\
\hline Transport & 0.385 & 0.302 & 0.226 & 0.282 & 0.365 & 0.447 & 0.491 & 0.550 & 0.351 & 0.442 & 0.531 & 0.568 & 0.595 \\
\hline $\begin{array}{l}\text { Statistics and } \\
\text { Probability* }\end{array}$ & 0.468 & 0.411 & 0.392 & 0.442 & 0.470 & 0.471 & 0.445 & 0.377 & 0.451 & 0.459 & 0.482 & 0.590 & 0.598 \\
\hline
\end{tabular}

Source: Journal Citation Reports Social Science Edition and * Science Edition. 

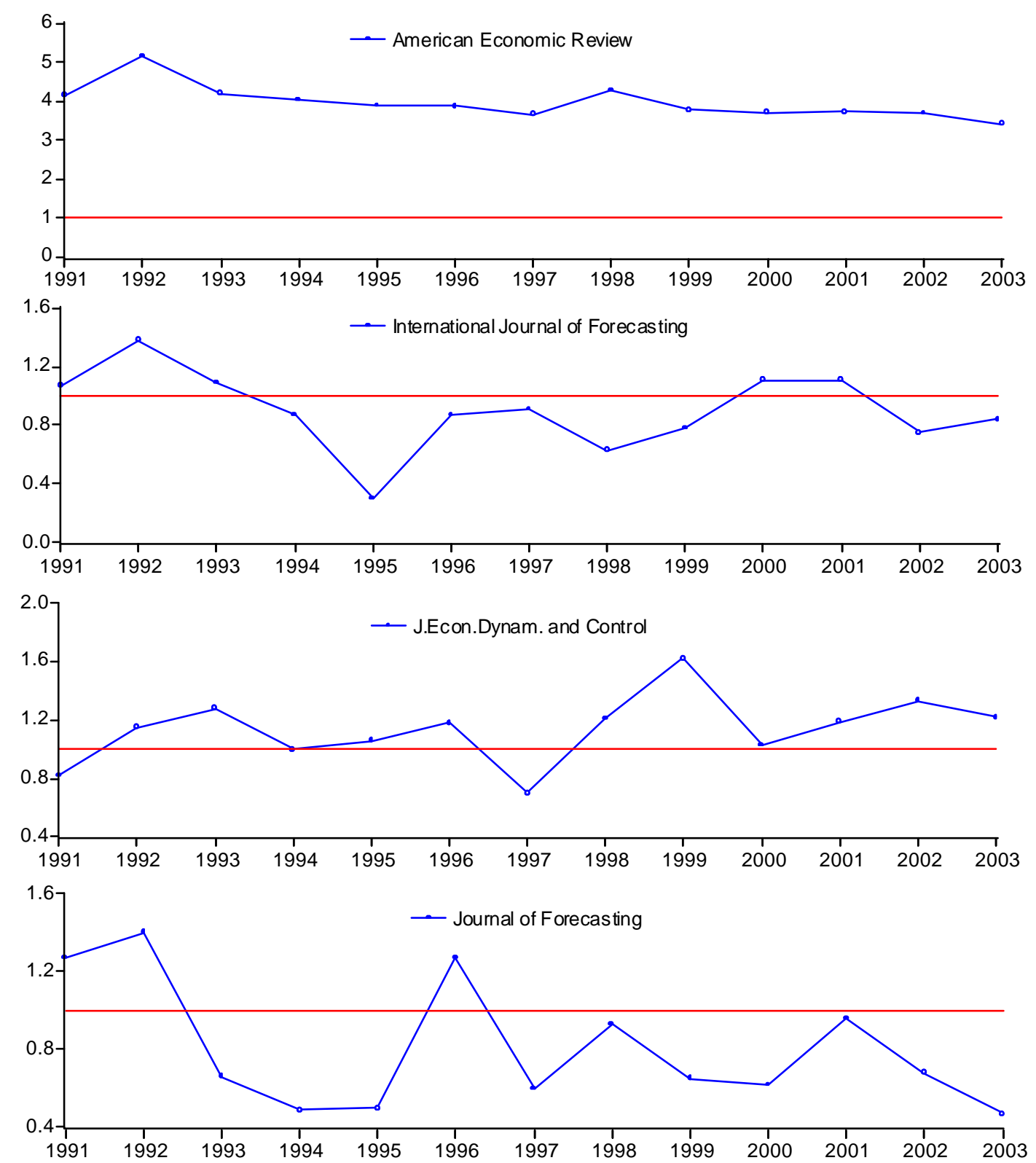

Figure 1: Normalized impact factors for several journals. 1991-2003 


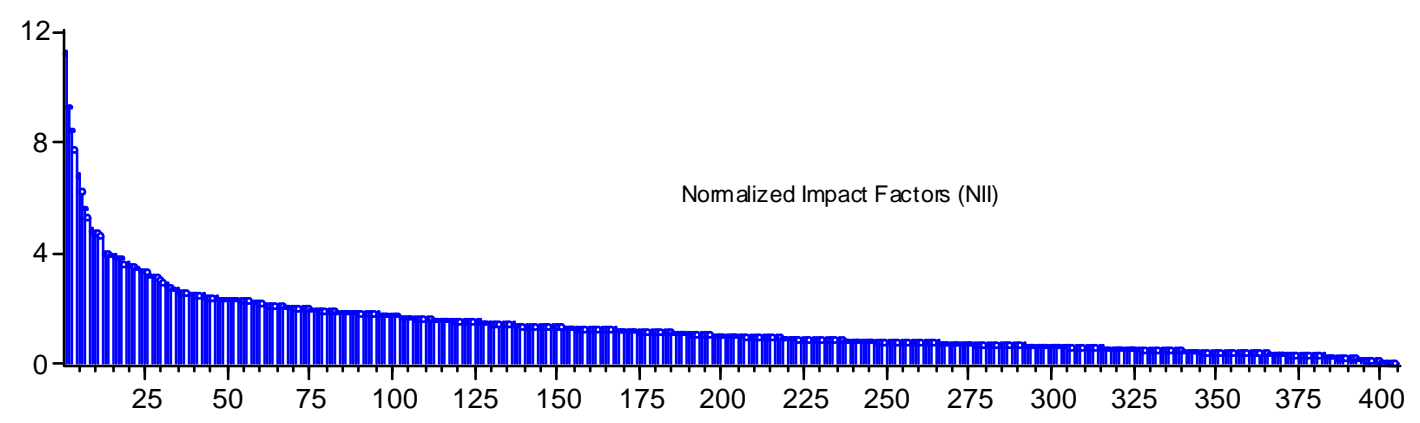

Figure 2: Normalized impact factors for all journals in 2003 


\section{References}

Amin, M. and M. Mabe, 2000, Impact factors: Use and abuse. Perspectives in Publishing. Elsevier Science, 1-6.

Bergantiños, G., da Rocha, J. M. and Palomé, P., 2002, La investigación española en economía, 1995-1999, Investigaciones Económicas 26, 373-392.

Bosch, X., 2003, Brain drain robbing Europe of its brightest young scientists, The Lancet 361, 2210-2211.

Brown, L., 1996, Influential accounting articles, individuals, Ph.D. granting institutions and faculties: A citational analysis, Accounting, Organizations and Society, 21, 7: 723-754.

Brown, L.D. and Huefner, R.J., 1994, Familiartiy with and perceived quality of accounting journals: Views of senior accounting faculty in leading US MBA Programs, Contemporary Accounting Research 11, 1, 223-250.

Brown, L.D., Vasarhelyi, M.A. and Gardner, J., 1993, Accounting research directory: The database of accounting literature (Sage: Beverly Hills).

de Bruin, R.E., Kint, A., Luwel, M. and Moed, H.F., 1993, A study of research evaluation and planning, Research Evaluation 3, 1-14.

Dolado, J. J., García Romero, A. and Zamarro, G., 2002, Publishing performance in economics: Spanish rankings (1990-1999), Spanish Economic Review 5, 85-100.

Eichenberger, R and Frey, B.S., 2000, Europe's eminent economists: A quantitative analysis. Institute for Research in Economics Working Paper Series \# 11424-0459. University of Zurich.

Frey, B. S. and Eichengerger, R., 1992, Economics and economists: a European perspective. American Economic Review 82(2), 216-220.

Frey, B. S. and Eichenberger, R., 1993b, American and European economics and economists. Journal of Economic Perspectives 7(4), 185-193.

García, P. Montañés, A. and Sanz, F., 1999, La investigación en Economía en España: Mercado nacional versus mercado internacional. Revista de Economía Aplicada, 20, 167-187.

Jiménez-Contreras, E., de Moya, F. and Delgado, E., 2003, The evolution of research activity in Spain. The impact of the National Commission of the Evaluation of Research Activity (CNEAI). Research Policy 32, 123-142. 
Johnson, J. L. and Podsakoff, P. M., 1994, Journal influence in the field of management: An analysis using Salancik's index in a dependency framework. Academy of Management Journal 37, 1392-1407.

Kalaitzidakis, P., Mamuneas, P. T. and Stengos, T., 1999, European economics: An analysis based on publications in the core journals, European Economic Review 43, 11501168 .

Kalaitzidakis, P., Mamuneas, P. T. and Stengos, T., 2003, Rankings of academic journals and institutions in economics, Journal of the European Economic Association 1, 1346-1366.

Lowe, A. and Locke, J., 2005, Perceptions of journal quality and research paradigm: Results of a web-based survey of British accounting academics, Accounting, Organizations and Society, 30, 1: 81-98.

Lubrano, M. and Protopopescu, C. , 2004, Density inference for ranking European research systems in the field of economics, Journal of Econometrics 123, 345-369.

Moed, H. F., 2002, The impact-factors debate: The ISI's uses and limits. Nature, 415, 731-732.

Moed, H. F. and van Leeuwen, Th. N., 1995, Improving the accuracy of Institute for Scientific Information's journal impact factors, Journal of the American Society for Information Science 46, 461-467.

Moed, H. F. and van Leeuwen, Th. N., 1996, Impact factors can mislead. Nature, 381, 186.

Nederhof, A. J., 1989, Books and chapters are not to be neglected in measuring research productivity. American Psychologist, 44, 734-735.

Nederhof, A. J. and van Raan, A. F. J., 1993, A biblometric analysis of six economics research groups: A comparison with peer review. Research Policy, 22, 353-368.

Perotti, R., 2002, The Italian system: rules versus incentives, mimeo.

Portes, R., 1987, Economics in Europe. European Economic Review 31, 1329-40.

Thursby, J. G., 2000, What do we say about ourselves and what does it mean? Yet another look at economics department research. Journal of Economic Literature 38, 383-404.

Van Fleet, D. D., McWilliams, A. and Siegel, D. S., 2000, A theoretical and empirical analysis of journal rankings: The case of formal lists. Journal of Management 26 (5), 839-861. 
Van Leeuwen, Th. N. and Moed, H. F., 2002. Development and application of journal impact measures in the Dutch science fiction system, Scientometrics, 53, 249-266.

Van Leeuwen, Th. N., Visser, M. J., Moed, H. F., Nederhof, T. J. and Van Raan, A. F. J., 2003. The Holy Grail of science policy: Exploring and combining bibliometric tools in search of scientific excellence, Scientometrics, 57, 257-280.

Villar, A., forthcoming, La evaluación de la investigación en economía, mimeo, Revista Valenciana de Economía y Hacienda.

Whitley, R., 2003, Competition and pluralism in the public sciences: the impact of institutional frameworks on the organisation of academic science. Research Policy, 32, 10151029. 
NOTAS 